\title{
A CATALOGUE OF THE TROMBICULINAE, OR CHIGGER MITES, OF THE NEW WORLD, WITH NEW GENERA AND SPECIES AND A KEY TO THE GENERA
}

\author{
By H. E. Ewing
}

Entomologist, Bureau of Eniomology, United States Department of Agriculture

Interest in chigger mites has been greatly increased in recent years by the discovery that they are concerned in the transmission of certain typhuslike diseases of man. This interest, although largely confined to medical men, has nevertheless so stimulated work on the taxonomy of the group that to-day there are known to science about 100 species. These are nearly all recently described and have been reported from most of the larger geographical units of the warmer regions of the world. They have been described by about a dozen scientists and in a much larger number of scientific journals, so that the time is now rather opportune for bringing together into a single paper some of the more important taxonomic data dealing with chiggers. Some of these taxonomic facts are here presented in the form of a synopsis of the known genera and others in the form of an annotated catalogue of the species of the New World. In addition, descriptions are given of 2 new genera and 11 new species.

The term "chigger mites" has been applied by the writer in the past, and is applied by him in this paper, to those acarids of the family Trombidiidae whose larvae parasitize vertebrates. The term "chigger," however, should be restricted to the larval form of a chigger mite. Rearing experiments indicate, so far as known, that all these vertebrate-infesting larvae of Trombidiidae are the young of adults that belong to the genus Trombicula Berlese, in the original sense in which this genus was used. The boundaries, therefore, of the subfamily Trombiculinae should be restricted to those given originally by Berlese to his collective genus Trombicula.

No. 2908.-Proceedings U. S. National Museum, Vol. 80, Art. 8. 


\section{THE GENERA OF TROMBICULINAE}

The writer gave a synopsis of the genera of the subfamily Trombiculinae in his Manual of External Parasites, published in June, 1929. Here it is intended to revise and extend that synopsis. Just how many of the genera of Trombidiidae, based upon larval characters, should be placed in the Trombiculinae is not known. Undoubtedly some of the unattached larvae that have been described have hosts that are vertebrates. Also it has been shown that vertebrate-infesting larvae may accidentally be resting on an invertebrate host or possibly some of them may have invertebrates as unnatural hosts.

KEY TO THE GENERA OF THE SUBFAMILY TROMBICULINAE, BASED ON LARVAL, CHARACTERS

1. Dorsal plate bearing six setae, exclusive of the pseudostigmatic organs.

Dorsal plate bearing less than six setae, exclusive of the pseudostigmatic organs

2. Four of the six setae, borne by dorsal plate, situated along its anterior margin; dorsal plate broader than long

Only two of the six setae, borne by dorsal plate, situated along its anterior margin; dorsal plate much longer than broad; head of pseudostigmatic organs spindle-shaped_..... Schöngastiella Hirst.

3. Dorsal plate with a median, anterior, knoblike process, but without crista___._. Leeuwenhoekia Oudemans.

Dorsal plate without anterior process, but frequently with a crista________._. Hannemania Oudemans.

4. Dorsal plate with five setae, exclusive of the pseudostigmatic organs; antero-median seta present; pseudostigmatic organs setiform, flagelliform, clavate, or capitate

Dorsal plate with only four setae, exclusive of the pseudostigmatic organs; antero-median seta lacking; pseudostigmatic

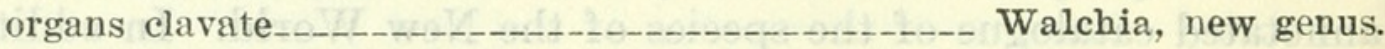

5. Pseudostigmatic organs strongly clavate or capitate 6.

Pseudostigmatic organs setiform or flagelliform and frequently with barbs

6. Chelicerae armed with a row of teeth above; palpal claw usually bifurcate Schöngastia Oudemans.

Chelicerae each with not more than one dorsal tooth; palpal claw trifurcate

Neoschöngastia Ewing.

7. Each chelicera with a row of teeth above; ventral tooth may be lacking

Each chelicera never with more than a single dorsal tooth; ventral tooth always present

Trombicula Berlese.

8. Several subequal dorsal teeth present on each chelicera; dorsal plate well developed; antero-median seta pectinate. Not endoparasitic in habits

Odontacarus Ewing.

Three unequal dorsal teeth on each chelicera; dorsal plate vestigial or lacking; antero-median seta simple. Living under the surface of the skin of amphibians 
A CAtalogue of THE CHIgger mites OF THE NEW WORLD

In this catalogue the synonymy of various species is given where known. Representatives of some, however, have not been seen by the writer. The probable synonymy of these is indicated in the appended notes.

\section{Family TROMBIDIIDAE \\ Subfamily TrombiculinaE \\ Genus HANNEMANIA Oudemans}

1911. Hannemania Oudemans, Ent. Ber., vol. 3, p. 137; 1912, Zool. Jahrb. Suppl. 14, Heft 1, p. 71.

\section{HANNEMANIA ARGENTINA Lahille}

1927. Hannemania argentina LAHILle, Rev. Univ. Buenos Aires, vol. 24, no. 5, p. 1293 , pl. 2. (The paper in which $H$. argentina is described is not in Washington libraries.)

\section{HANNEMANIA DUNNI Sambon}

1928. Hannemania dunni SAMBon, Ann. Trop. Med. and Parasit., vol. 22, p. 129, fig. 17.

Type host.-A salamander (Desmognathus fuscus fuscus). Type locality._-"Eastern United States of America."

\section{HANNEMANIA EDWARDSI Sambon}

1928. Hannemania edwardsi Sambon, Ann. Trop. Med. and Parasit., vol. 22, p. 123, figs. 10-12.

Type host.-A toad (Bufo variegatus).

Type Tocality.-Lake Nahuel Huapi, Puerto Blest, Argentine Andes.

HANNEMANIA ELTONI Sambon

1928. Hannemania eltoni Sambon, Ann. Trop. Med. and Parasit., vol. 22, p. 129, fig. 16.

Type host.-A frog (Rana sphenocephala).

Type locality.-San Antonio, Tex.

HANNEMANIA HOBDAYI Sambon

1928. Hannemania hobdayi Sambon, Ann. Trop. Med. and Parasit., vol. 22, p. 126, fig. 13.

Type host.-Pleurodema bufonina.

Type locality.-Rio Negro Territory, Argentina. 
HANNEMANIA HYLAE (Ewing)

1925. Trombicula hylae EwIng, Proc. Ent. Soc. Washington, vol. 27, p. 146; 1926, Ann. Ent. Soc. Amer., vol. 19, p. 266, figs. 1-4.

Type host.-A tree toad (Hyla arenicolor).

Type locality.-Cottonwood Creek, San Diego County, Calif.

The nymph and adult stages of this species have been obtained by experimental rearing.

\section{HANNEMANIA HYLODEUS (Oudemans)}

1910. Heterothrombidium hylodeus Oudemans, Ent. Ber., vol. 3, no. 54, p. 88. 1911. Hannemania hylodeus Oudemans, Ent. Ber., vol. 3, no. 58, p. 137; 1912, Zool. Jahrb., Suppl. 14, Heft 1, p. 71, fig. 2.

Type host.-A frog (Hylodes sp.).

Type locality.-Brazil.

This is the type species of the genus. In it there is a well-developed crista between the pseudostigmata, a character missing from most of the species.

\section{HANNEMANIA NEWSTEADI Sambon}

1928. Hannemania newsteadi Sambon, Ann. Trop. Med. and Parasit., vol. 22, p. 127 , fig. 14.

Type host.-A tree frog (Hyla rubra).

Type locality.-Urucum, Matto Grosso, Brazil.

\section{HANNEMANIA PATTONI Sambon}

1928. Hannemania pattoni Sambon, Ann. Trop. Med. and Parasit., vol. 22, p. 130, fig. 18.

Type host.-Borborocoetes taeniatus.

Type locality.-Temuco, Chile.

\section{HANNEMANIA SAMBONI, new name ${ }^{1}$}

1928. Hannemania argentina SAMBon, Ann. Trop. Med. and Parasit., vol. 22, p. 131, fig. 19.

Type host.-Pleurodema bibroni.

Type locality.-Rio Negro Territory, Argentina.

\section{HANNEMANIA STEPHENSI Sambon}

1928. Hannemania stephensi SAMBoN, Ann. Trop. Med. and Parasit., vol. 22, p. 127, fig. 15 .

Type host.-A frog (Eleutherodactylus gollmeri).

Type locality.-Tombador, Matto Grosso, Brazil.

${ }^{1}$ For H. argentina Sambon (1928), preoccupied by $H$. argentina Lahille (1927). 


\section{Genus LEEUWENHOEKIA Oudemans}

1911. Leeuwenhoekia Oudemans, Ent. Ber., vol. 3, no. 58, p. 137; 1912, Zool. Jahrb., Suppl. 14, Heft 1, p 74.

\section{LEEUWENHOEKIA VERDUNI (Oudemans)}

1910. Heterothrombidium verduni Oudemans, Ent. Ber., vol. 3, no. 54, p. 88.

1911. Leeuwenhoekia verduni Oudemans, Ent. Ber. vol. 3, no. 58, p. 138; 1912. Zool. Jahrb., Supp. 14, Heft 1, p. 74, fig. R.

Type host.-Opossum (Didelphis opossum).

Type locality.-South Brazil.

\section{Genus NEOSCHÖNGASTIA Ewing}

1929. Neoschöngastia Ewing, Manual of external parasites, p. 187.

Species of Neoschöngastia differ from those of Schöngastia in being without the dorsal row of teeth on each chelicera. A single dorsal tooth is usually present.

\section{NEOSCHÖNGASTIA AMERICANA (Hirst)}

1921. Schöngastia americana Hinst, Ann. Mag. Nat. Hist., ser. 9, vol. 7, p. 37; 1922, Brit. Mus. Econ. Ser. no. 13, p. 78, fig. 45.

Type host.-Domestic fowl.

Type locality.-Dallas, Tex.

This species is a serious pest of chickens in the southern part of the United States.

\section{NEOSCHÖNGASTIA CALIFORNICA (Ewing)}

1925. Schöngastia californica EwING, Amer. Journ. Trop. Med., vol. 5, p. 262.

Type host.-A ground squirrel.

Type locality.-Topaz, Calif.

\section{NEOSCHÖNGASTIA PEROMYSCI (Ewing)}

1929. Schöngastia peromysci EwING, Ent. News, vol. 40, p. 296.

Type host.-White-footed mouse (Peromyscus leucopus noveboracensis).

Type locality.-Sturbridge, Mass.

\section{NEOSCHÖNGASTIA SCIURICOLA (Ewing)}

1925. Schöngastia sciuricola EwING, Amer. Journ. Trop. Med., vol. 5, p. 261.

Type host.-Red squirrel (Sciurus hudsonicus richardsonii).

Type locality.-Florence, Mont. 


\section{NEOSCHÖNGASTIA TROUESSARTI (Oudemans)}

1910. Schöngastia trouessarti OUdEMANs, Ent. Ber., vol. 3, no. 54, p. 87 ; 1912,

Zool. Jahrb., Suppl 14, Heft 1, p. 65, fig. O.

Type host.-Opossum (Didelphis opossum).

Type locality.-South Brazil.

\section{Genus ODONTACARUS Ewing}

1929. Odontacarus Ewing, Manual of external parasites, p. 188.

In Odontacarus each chelicera is provided with a dorsal row of teeth; in Trombicula with a single tooth.

ODONTACARUS AUSTRALIS (Ewing)

1929. Trombicula australis EwING, Proc. Ent. Soc. Washington, vol. 31, p. 10.

Type host.-A lizard (Tropiduras peruvianus).

Type locality.-Verrugas Cañon, Lima, Peru.

\section{ODONTACARUS DENTATUS (Ewing)}

1925. Trombicula dentata Ewine, Amer. Journ. Trop. Med., vol. 5, p. 257, fig. 3.

Type host.-White-tailed deer (Odocoileus couesi ?).

Type locality.-Sonora, Tex.

\section{Genus TROMBICULA Berlese}

1905. Trombicula Beriese, Redia, vol. 2, p. 155 (no generic description) ; 1912, Redia, vol. 8, p. 83.-1915, Banks, U. S. Dept. Agr., Office of the Secretary, Rep. 108 [Contr. from Bur. of Ent.], p. 43.

1916. Leptotrombidium Nagayo, Miyakawa, Mitamura, and Imamura, Dobuts.

z. Tokyo, vol. 28, p. ?.

1925. Neotrombicula Hinst (subgenus), Nature, vol. 116, p. 609.

\section{TROMBICULA ALLEEI Ewing}

1926. Trombicula alleei Ewing, Ent. News, vol. 37, p. 111.

Type host.-None.

Type locality.-Barro Colorado Island, Canal Zone.

Description based on adult form. Larva unknown.

TROMBICULA BATATAS (Linnaeus)

1758. Acarus batatas Linnaeus, Systema naturae, ed. 10, vol. 1, Gen. 235, No. 22, p. 617.-1775, MüLLER, Vollständiges Natursystem, vol. 5, pt. 2, No. 25, p. 1055.

1904. Pattata-luis van Stockum, Tijdschr. Kon. Nederlandsch Aardr.-kundig

Gen. 1904, Verslag. Saramacca-Exp., p. 22.

1905. Thrombidium batatas Oudemans, Nova Guinea, 1903, vol. 5, p. 148.

1912. Gen.? batatus OUdemans, Zool. Jahrb., Suppl. 14, Heft 1, p. 3.

Type host.-(?).

Type locality.-Surinam. 
The status of this species has not been definitely determined. It appears to be a Trombicula sp., and Oudemans claims it is the same as his Microthrombidium helleri, which is a typical Trombicula species.

TROMBICULA BISIGNATA Ewing

1929. Trombicula bisignata Ewing, Ent. News, vol. 40, p. 295.

Type host.--Meadow mouse (Microtus pennsylvanicus pennsylvanicus).

Type locality.-Mount Katahdin, Me.

\section{TROMBICULA BRASILIENSIS Ewing}

1925. Trombicula brasiliensis Ewing, Proc. Ent. Soc. Washington, vol. 27, p. 92.

Type host.-(?).

Type locality.-Manáos, Brazil.

TROMBICULA BRUYANTI (Oudemans)

1910. Microthrombidium bruyanti Oudemans, Ent. Ber., vol. 3, no. 54, p. 85; 1912, Zool. Jahrb., Suppl. 14, Heft 1, p. 26, fig. F.

Type host.-Opossum (Didelphis opossum).

Type locality.-South Brazil.

TROMBICULA COARCTATA (Berlese)

1888. Trombidium coarctatum BerLese, Bull. Soc. Ent. Italiana, Ann. 20, p. 179,

Tab. V, fig. 5.-1901, Leonard, Zool. Anz., Band 25, p. 17.

1912. Trombicula coarotata Berlese, Redia, vol. 80, p. 91, fig. 42.-1921, Ewing,

Ann. Ent. Soc. Amer., vol. 13, p. 382, fig. 1.

Type host.-Described from adults.

Type locality.-Buenos Aires, Argentina, and Rio Apa, Paraguay. This species has been confused by some authors with the Kedani mite, Trombicula akamushi (Brumpt), but it is distinct.

\section{TROMBICULA FLUI van Thiel}

1930. Trombicula flui van Thiel, Parasitology, vol. 22, p. 347 , figs. $1,2$.

Type host.--Man.

Type locality.-Surinam.

This species may be a synonym of Acarus batatas Linnacus.

TROMBICULA GÖLDII (Oudemans)

1910. Microthrombidium göldii OUdEMAns, Ent. Ber., vol. 3, no. 5̃, p. 84 ; 1912,

Zool. Jahrb., Suppl. 14, Heft 1, p. 13, fig. B.

Type host.-Dasyprocta agouti.

Type locality.-Brazil. 


\section{TROMBICULA GUINEENSE (Bruyant and Joyeux)}

1913. Microtrombidium guineense Bruyant and Joyeux, Bull. Soc. Path. Exot., vol. 6 , no. 3 , p. 202 , figs. $1-4$.

Type hosts.-Domestic fowl and two monkeys (Cercopithecus mubr and $C$. callitrichus).

Type locality.-French Guiana.

May be a synonym of Acarus batatas Linnaeus.

\section{TROMBICULA HARPERI Ewing}

1928. Trombicula harperi Ewing, Proc. Ent. Soc. Washington, vol. 30, p. 79.

Type host.-Woodland jumping mouse (Napaeozapus insignis). Type locality.-Heart Lake, Essex County, N. Y.

\section{TROMBICULA HELLERI (Oudemans)}

1911. Microthrombidium helleri Oudemans, Ent. Ber., vol. 30, p. 120; 1912, Zool. Jahrb., Suppl. 14, Heft 1, p. 15, fig. C.

Type host.-A beetle (Passalus sp.).

Type locality.-Surinam.

According to Oudemans, this species is a synonym of the Acarus (Trombicula) batatus of Linnaeus. Beetles probably are not true hosts of this mite.

\section{TROMBICULA INSULARIS Ewing}

1925. Trombicula insularis EwIng, Amer. Journ. Trop. Med., vol. 5, p. 260.

Type host.-A lizard (Anolis cybotes).

Type locality.-Santo Domingo.

\section{TROMBICULA IRRITANS (Riley)}

1873. Leptus irritans RILEY, Amer. Nat., vol. 7, p. 16.

1877. Tetranychus tlalsahuate MurRay, Economic entomology, Aptera, p. 113.

1886. Leptus irritans Osborn and Underwood, Can. Ent., vol. 18, p. 6.-1897,

Lugger, 2d Ann. Rep. Ent. Minnesota Exp. Sta., p. 82.

1892. Trombidium tlalzahuatl Dugés, El Estudio, vol. 4, no. 6, p. 198, 1 pl.

1910. Microthrombidium alfreddugèsi Oudemans, Ent. Ber., vol. 3, no. 54, p. 84.

1911. Mierothrombidium tlalzahuatl Oudemans, Ent. Ber., vol. 3, no. 57, pp. 120

and 121; 1912, Zool. Jahrb., Suppl. 14, Heft 1, p. 18, fig. D.-1918, Ewina

and Hartselt, Journ. Econ. Ent., vol. 11, p. 261, fig. 10c.

1918. "Chigger mite” How ARD, 17th Rep. State Ent. Minnesota, p. 130, pl. 11.

1921. Trombicula cinnabaris Ewing, Ann. Ent. Soc. Amer., vol. 13, p. 387, fig. 3.

1921. Leptus (Trombicula?) similis Hirst, Ann. Mag. Nat. Hist., ser. 9, vol. 7,

p. $37 ; 1922$, Brit. Mus. Econ. Ser. no. 13, p. 78, fig. 44.

1923. Trombicula tlalzahuatl Ewing, Journ. Agr. Res., vol. 26, no. 9, p. 401.

1925. Trombicula irritans Ewing, Proc. Biol. Soc. Washington, vol. 38, pl. 17, fig. 1; 1925, Amer. Journ. Trop. Med., vol. 5, p. 253, fig. 1. 
Type host.-Man.

Type locality.-United States.

The nymphs and adults of this species have been obtained by rearing.

TROMBICULA JAPA (Ribeyro and Bambarén)

1922. Leptus japa Ribeyro and Bambarén, Arch. Asoc. Peruana para el Prog.

Cien., vol. 2, fasc. 2, p. 115, 3 figs.

Type host.-(?).

Type locality.-Peru.

The generic status of this species is in doubt. It appears to belong to Trombicula.

TROMBICULA MICROTI Ewing

1928. Trombicula microti Ewing, Proc. Ent. Soc. Washington, vol, 30, p. 80.

Type host.-Meadow mouse (Microtus richardsoni macropus).

Type locality.-Wyoming.

\section{TROMBICULA MYOTIS Ewing}

1929. Trombicula myotis EwING, Ent. News, vol. 40, p. 294.

Type host.-Little brown bat (Myotis lucifugus lucifugus).

Type locality.-Mount Katahdin, Me.

\section{TROMBICULA OREGONENSIS Ewing}

1929. Trombicula oregonensis EwINg, Proc. Ent. Soc. Washington, vol. 31, p. 11.

Type host.-A mole (Scapanus sp.).

Type locality.-Corvallis, Oreg.

\section{TROMBICULA PANAMENSIS Ewing}

1925. Trombicula panamensis Ewing, Amer. Journ. Trop. Med., vol. 5, p. 259.

Type host.-A cotton rat (Sigmodon hispidus chiriquensis).

Type locality.-Balboa, Panama.

\section{TROMBICULA PERUVIANA Ewing}

1926. Trombicula peruviana EwING, Ent. News, vol. 37, p. 112.

Type host.-None.

Type locality.-Peru.

Description based on adult form. Larva unknown. Species may not belong to this genus; rearing of larva will tell.

\section{TROMBICULA SHANNONI Ewing}

1929. Trombicula shannoni Ewing, Proc. Ent. Soc. Washington, vol. 31, p. 10.

Type host.-House cat (Felis domestica).

Type locality.-Verrugas Cañon, Lima, Peru.

$70404-31-2$ 


\section{TROMBICULA SPLENDENS Ewing}

1913. Trombicula splendens Ewing, Bull. Amer. Mus. Nat. Hist., vol. 32, p. 113

pl. 7, fig. 5; 1921, Ann. Ent. Soc. Amer., vol. 13, p. 386, fig. 2.

Type host.-None (described from adult).

Type locality.-Portage, Wis.

\section{TROMBICULA. TINAMI (Oudemans)}

1910. Microthrombidium tinami Oudemans, Ent. Ber., vol. 3, no. 54, p. 84 ; 1912, Zool. Jahrb., Suppl. 14, Heft 1, p. 24, fig. E.

Type host.-A tinamou (Crypturus noctivagus).

Type locality.-Brazil.

\section{TROMBICULA THOMASI (Ondemans)}

1910. Microthrombidium thomasi Oudemans, Ent. Ber., vol. 3, no. 54, p. 84; 1912, Zool. Jahrb., Suppl. 14, Heft 1, p. 28, fig. G.

Type host.-A mouse (Akodon jelskii).

Type locality.-Central Peru.

\section{TROMBICULA TROPICA Ewing}

1925. Trombicula irritans var. tropica Ewing, Amer. Journ. Trop. Med., vol. 5, p. 258.

Type host.-A lizard (Anadia taeniata).

Type locality.-Chama River, Venezuela.

\section{TROMBICULA WHARTONI Ewing}

1929. Trombicula whartoni EwING, Ent. News, vol. 40, p. 296.

Type host.-A bird.

Type locality.-Summerville, S. C.

\section{TROMBICULA YORKEI Sambon}

1928. Trombicula yorkei Sambon, Ann. Trop. Med. and Parasit, vol. 22, p. 119, fig. 6.

Type host.-A tree frog (Hyla rubra).

Type locality.-Urucum, Matto Grosso, Brazil.

DESCRIPTIONS OF NEW GENERA OF TROMBICULINAE

WALCHIA, new genus

Palpi rounded laterally; palpal claw trifurcate; chelicerae each with a short chela. Dorsal plate present, as long as broad; bearing only four setae, exclusive of the pseudostigmatic organs, these setae being a pair of antero-laterals and a pair of postero-laterals. Pseudostigmatic organs clavate and pectinate; eyes either lacking or represented by vestiges of a single pair. Dorsal abdominal 
setae moderate in size and number, less than 50 present. Legs moderate; second pair shortest; last pair longest.

Type species.-Trombicula glabrum Walch.

This genus stands alone in having only four true setae on the dorsal plate. It is evidently most nearly related to Schöngastia Oudemans. Only the type is included. It should now be known as Walchia glabrum (Walch).

\section{ENDOTROMBICULA, new genus}

Plate 3, Figures 1, 2

Palpi rounded laterally; palpal claw trifurcate. Chelicerae each with three dorsal teeth and one latero-ventral. Dorsal plate very poorly sclerotized, indistinct, with five setae in addition to the pseudostigmatic organs; median seta simple. Both pairs of eyes well developed, each eye having a complete cornea. Abdominal setae short, inconspicuous. Each tarsus armed distally with two simple, subequal, lateral claws and one longer, simple, and more slender middle claw. Tarsus I with a simple dorsal spine and a simple subterminal seta or spine.

Type species.-Endotrombicula penetrans, new species (p. 16).

Endotrombicula should come between Hannemania Oudemans and Odontacarus Ewing, being more closely related to the latter genus, from which it differs in having fewer and a definite number of dorsal teeth on the chelicerae, and a vestigial dorsal plate, as well as in a few other characters.

\section{DESCRIPTIONS OF NEW SPECIES OF TROMBICULINAE}

TROMBICULA BLARINAE, new species

Plate 1, Figure 1

Palpi elbowed, having the second segment angulate laterally; first seta strongly pectinate, almost plumose; second seta shorter than the first and with several barbs; third seta with several barbs; palpal thumb small, scarcely exceeding the fourth segment; palpal claw slender and trifurcate, two accessory claws being small and situated near the apex. Chelicerae stout, sharply pointed and with minute upper tooth; lower tooth very minute or lacking. Dorsal plate more than twice as broad as long, front margin incurved between median and each fronto-lateral seta, but hind margin outwardly rounded behind each pseudostigma; all setae borne by dorsal plate strongly pectinate, postero-lateral pair longer than the others. Pseudostigmata situated about their diameter from posterior margin of dorsal plate and about as far from each other as each is from the 
postero-lateral seta on its side; in front of each pseudostigma is a posteriorly concave, crescentic slit; pseudostigmatic organs minute, simple, vestigial. Eyes lacking. Dorsal abdominal setae about 36, of which 20 are arranged into two transverse rows of 10 each, all short and strongly pectinate. Legs short, last pair longest. Tarsus I with dorsal spine situated almost twice its length from base of segment and with a simple subapical seta.

Length of unengorged specimen, $0.17 \mathrm{~mm}$; width, $0.13 \mathrm{~mm}$.

Type host.-Short-tailed shrew (Blarina brevicauda).

Type locality.-Washington, D. C.

Type slide.-U.S.N.M. No. 1018.

Described from many specimens taken from Blarina brevicauda, Rock Creek Park, Washington, D. C., collected by J. C. Jones, some on September 18 and some on September 20, 1929. Also from one specimen of Peromyscus leucopus taken at the same place by the same collector, on September 20, 1929.

\section{TROMBICULA DUNNI, new species}

Plate 1, Figure 2

Palpi large, not elbowed, second segment broadly rounded on outside; first seta with two to four barbs; second seta with one barb; third seta with two to three barbs. Palpal thumb small; palpal claw usually bifurcate, with a very large, curved, inner prong and a smaller, shorter, almost straight, outer prong; traces of a smaller, inner third prong sometimes seen. Chelicerae strongly curved. Dorsal plate broader than long, front margin slightly incurved on each side of median seta, posterior margin broadly but not evenly outcurved; pseudostigmata situated far from each other and about halfway from the anterior to posterior margin of dorsal plate; pseudostigmatic organs long, slender, setiform, simple. Immediately behind each pseudostigma is an indistinct straight slit or line. Eyes double but corneas of posterior ones lacking, situated about one and a half times the diameter of the cornea of one of the anterior eyes from the lateral margins of the dorsal plate. Dorsal abdominal setae 20 , arranged in irregular transverse rows as follows: I-6, II-6, III-4, IV-4. Legs medium, second pair the shortest; tarsus I with dorsal spine situated about one and a half times its length from base of segment, subapical seta about twice as long as dorsal spine.

Length of unengorged larva, $0.16 \mathrm{~mm}$; width, $0.11 \mathrm{~mm}$.

Type host.-An agouti (Dasyprocta punctata nuchalis).

Type locality.-Chiriqui, Panama.

Type stide.-U.S.N.M. No. 1019.

Described from several specimens taken from type host, Camp Pital, Chiriqui, Panama, October 26, 1929, by L. H. Dunn and from 
seven specimens taken from three young coatis (Nasua narica panamensis), collected at the same place by the same person.

\section{TROMBICULA CERVULICOLA, new species}

\section{Plate 1, Figure 3}

Palpi stout, not angulate; first seta strongly pectinate, subplumose; second seta with three to four very long barbs; third seta with a few shorter barbs. Palpal claw tricleft, short, strongly curved; inner prong longest, outer shortest, and middle intermediate. Dorsal plate broader than long, front margin almost straight, posterior margin broadly and outwardly rounded; anterior setae subequal, shorter than the two postero-lateral setae. Pseudostigmata situated slightly behind the middle of the dorsal plate and about three times the diameter of each from each other; almost contiguous with the posterior boundary of each is a short, straight, diagonal slit; pseudostigmatic organs very long and slender, with about four or five barbs on the distal half of each. Anterior eyes well developed, each situated a little more than its diameter from the margin of the dorsal plate; posterior eyes vestigial, corneas lacking. About 26 dorsal setae present, not arranged into definite rows. Legs rather long, posterior pair longest; tarsus I with dorsal spine, spinelike and situated almost twice its length from the base of the segment; subapical seta of tarsus I spinelike.

Length of slightly engorged larva, $0.31 \mathrm{~mm}$.; width, $0.22 \mathrm{~mm}$.

Type host.-Barking deer (Cervulus aureus).

Type locality.-Muktesar, Kumaun, India.

Type stide.-U.S.N.M. No. 1020.

Three specimens at hand, all taken from type host, at type locality, March, 1930, by Mr. Cooper. This species is near acuscutellaris Walch, but the dorsal shield is not angulate posteriorly, and the pseudostigmatic organs have fewer barbs.

TROMBICULA PIERCEI, new species

Plate 1, Figure 4

Palpi slender, not angulate laterally; first, second, and third setae long and simple; claw curved and very slender, tricleft distally with middle prong largest and lateral prongs subequal; thumb very short, subterminal. Chelicerae each with upper and lower tooth prominent. Dorsal shield indistinct but broader than long; median seta more slender than the others; postero-lateral setae longer than antero-lateral. Pseudostigmata in front of line drawn between the two postero. lateral setae and situated a little more than their diameter apart; pseudostigmatic organs very long, almost straight, and with many 
barbs on distal two-thirds. Eyes subequal, both with corneas. Dorsal setae between 34 and 40 . Legs long and slender, tarsus I with dorsal spine almost equal to half of segment itself, subapical seta spinelike, but smaller and shorter than dorsal spine.

Length of partly engorged larva, $0.64 \mathrm{~mm}$.; width, $0.27 \mathrm{~mm}$.

Type host.-A bat (Hipposideros diadema griseus).

Type locality.-Barrio Buyog, Municipality Sagay, Occidental Negros, Philippine Islands.

Type slide.-U.S.N.M. No. 1021.

Described from nine specimens taken from type host, at type locality, by W. D. Pierce, May 23, 1928. The characters of the palpi mark off this species very distinctly from all others.

TROMBICULA CAVICOLA, new species

Plate 1, Figure 5

Palpi more moderate, subangulate laterally; first seta with many slender barbs, being subplumose; second seta subplumose; third seta shorter, but subplumose; palpal thumb stout, but longer than broad; palpal claw short, curved, and bifurcate, inner prong being much longer and stouter than outer. Ventral tooth of chelicerae sharp, dorsal tooth vestigial or lacking. Dorsal plate slightly broader than long, front margin almost straight, posterior margin broadly and evenly outcurved; setae very long; pseudostigmata behind line drawn between two postero-lateral setae and about three times the diameter of either from each other; pseudostigmatic organs long and simple. Eyes subequal, and both pairs provided with complete corneas. Dorsal abdominal setae long, straight, conspicuous, about 30 in number. Legs moderate, last pair longest; tarsus I with dorsal spine spinelike, curved and situated slightly behind the middle of the segment; subapical seta long, slender, but not surpassing claws.

Length of unengorged larva, $0.22 \mathrm{~mm}$; width, $0.14 \mathrm{~mm}$.

Type host.-None. Description based on unattached larvae.

Type locality.-Reynolds Cave, Ky.

Type slide.-U.S.N.M. No. 1022.

Four larvae at hand, all being taken at type locality in 1881, by a Mr. Tucker, a collector who specialized in collecting cave insects.

NEOSCHÖNGASTIA SIGNATOR, new species

Plate 2, Figure 1

Palpi conspicuous and angulate laterally along outer margin of second segment; first, second, and third setae each with many barbs, hence subplumose. Palpal thumb short, inconspicuous, not reaching to the middle of palpal claw, which is slender and trifurcate distally, 
the middle prongs being the largest. Dorsal plate broader than long, slightly incurved along anterior margin and produced backward into an angle behind each pseudostigma and with a conspicuous $\mathrm{V}$ shaped signature present in posterior half. Setae along the anterior margin of dorsal plate subequal and shorter than the postero-lateral setae. Pseudostigmata situated less than their diameter from the posterior margin of dorsal plate and about twice their diameter from each other; pseudostigmatic organs capitate, pedicel being about as long as diameter of head. Anterior and posterior corneas of eyes subequal, contiguous. Dorsal abdominal setae about 60, and for the most part arranged into five transverse rows. Legs moderate, last pair longest; tarsus I with dorsal spine situated its length from the base of the segment and with subapical seta moderate, somewhat spinelike, and extending slightly beyond the base of the claws.

Length of unengorged larva, $0.30 \mathrm{~mm}$.; width, $0.19 \mathrm{~mm}$.

Type host.-A wood rat.

Type locality.-Wilburton, Okla.

Type stide.-U.S.N.M. No. 1023.

Described from three specimens taken from type host, at type locality, by G. W. Stiles, March 17, 1929 (Bishopp, No. 8268).

NEOSCHÖNGASTIA SCELOPORI, new species

Plate 2, Figures 2, 3

Palpi not angulate but rounded laterally, first and second setae long, subplumose. Palpal thumb slightly swollen and extending to middle of palpal claw; the latter strongly curved and deeply trifurcate distally, the middle prong being the longest and the other two subequal. Chelicerae strongly curved, with the upper tooth very small, sharp and procurved, and with the lower one larger, stout, and directed backward. Dorsal plate but slightly broader than long, both anterior and posterior margins being almost straight. Median seta shorter than the antero-lateral ones and these slightly shorter than the postero-lateral setae. Pseudostigmata situated slightly behind middle of dorsal plate, and far laterally, near the lateral margins of the same; in front of each is a diagonal straight line. Pseudostigmatic organs with globose heads and pedicels equal in length to the diameters of the heads. Posterior eyes smaller than anterior but with corneas. Dorsal abdominal setae about 30. Legs moderate; tarsus I peculiar in that subapical seta is situated on a conspicuous tubercle, and part of the tarsus distal to it is attenuated; dorsal spine situated almost twice its length from base to the segment.

Length of partly engorged larva, $0.57 \mathrm{~mm}$.; width, $0.33 \mathrm{~mm}$.

Type host.-A lizard (Sceloporus spinosus). 
Type locality.-Uvalde, Tex.

Type stide.-U.S.N.M. No. 1024.

Four specimens at hand, all being taken from the type host, at the type locality, by F. Adams, July 13, 1928.

\section{NEOSCHÖNGASTIA BREVIPES, new species}

Plate 2, Figure 4

Palpus with second segment produced into an angle laterally; first seta plumose, second and third subplumose. Palpal thumb small, short, inconspicuous; palpal claw slender, curved, trifurcate distally, the middle prong surpassing the others, which are subequal. Chelicerae strongly curved and very sharp; teeth minute to vestigial. Dorsal plate about twice as broad as long, provided with an anterior projection bearing the median seta, posteriorly not broadly rounded; median seta slightly smaller than antero-lateral setae, postero-lateral setae longest. Pseudostigmata situated slightly behind a line drawn between the bases of the two postero-lateral setae and about as far from each other as each is from the postero-lateral seta on its side. First pair of eyes situated about three times their diameter from the dorsal plate, second pair degenerate, without corneas. Dorsal setae about 50, all but 6 being arranged into five transverse rows. Legs rather short; tarsus I with dorsal spine slightly curved and situated about its length from the base of the segment, subterminal seta somewhat spikelike and situated on a broad low tubercle.

Length of unengorged larva, $0.29 \mathrm{~mm}$.; width, $0.16 \mathrm{~mm}$.

Type host.-White-footed mouse (Peromyscus leucopus noveboracensis).

Type locality.-College Park, Md.

Type slide.-U.S.N.M. No. 1025.

Sixteen specimens obtained from the type host (individuals C. P. 2, C. P. 5, and C. P. 7) by H. S. Peters and the writer, May 3, 1929. This species is closely related to signator, new species, but differs from it in having about 10 less dorsal setae, the posterior eye degenerate, in the shape of the dorsal plate, and in a few other characters.

ENDOTROMBICULA PENETRANS, new species

Plate 3, Figures 1, 2

Palpi laterally rounded; first seta simple, second typically with two barbs, third with three barbs. Palpal claw trifurcate, middle prong much the stoutest, lateral prongs subequal, all prongs of about the same length. Palpal thumb longer than broad, not swollen, extending to middle of palpal claw. Chelicerae strongly curved and very sharp at apex, each with three sharp, recurved teeth on the upper margin and a vestigial lateral tooth near the ventral margin. Dorsal 
plate indistinct, slightly sclerotized along anterior margin; median seta shortest, simple; antero-lateral setae longest. Posterior eyes smaller than anterior, both pairs with corneas; posterior eye situated its diameter from anterior eye. Pseudostigmata situated their diameter apart; pseudostigmatic organs setiform, simple, very short. Dorsal abdominal setae small, short, inconspicuous, less than 30 in number. Legs short; tarsus I with dorsal spine situated two-thirds its length from the base of the segment, but very long, extending to base of tarsal pedicel; subterminal seta moderate, somewhat spinelike, not situated on a tubercle.

Length of engorged larva, $0.46 \mathrm{~mm}$; width, $0.28 \mathrm{~mm}$.

Type host.-A frog (Arthroleptis minutus).

Type locality.-Mount Sagalla, Kenya Colony, Africa.

Type slide.-U.S.N.M. No. 1026.

Many specimens received through Nathan Banks. Specimens taken from hosts collected by E. Heller in the year 1911 and determined by A. Loveridge. Stained sections of frog's skin show that the mites live in cavities under the growing layer of integumentary cells.

\section{HANNEMANIA HIRSUTA, new species}

Plate 3 , Figures 3,5

Palpi large, stout, rounded laterally; first seta with many barbs arranged on a single side, second seta simple, third with one barb. Palpal thumb small, short, extending only to the base of palpal claw. Palpal claw bifurcate, inner prong being much stouter and consiclerably longer than outer. Chelicerae not strongly curved, without dorsal teeth, but each with a row of laterally projecting ventral teeth, the teeth in this row diminishing in size from apex to base of segment. Dorsal plate strongly incurved along front margin and outwardly rounded behind, being subangulate at median line; submedian setae about equal to antero-lateral ones but shorter than postero-lateral setae. Pseudostigmata slightly nearer each other than either is to the postero-lateral seta on its own side, situated along a line drawn between the postero-lateral setae; approximate to each pseudostigmata, both in front and behind, is a curved slit. Pseudostigmatic organs very long, somewhat flagelliform, and simple. Anterior and posterior eyes equally developed, contiguous, and both pairs provided with corneas. Dorsal abdominal setae very numerous, being more than 100. Legs moderate in size; tarsus I with a short dorsal spine situated over twice its length from base of segment, subapical seta extending to about the base of tarsal claws, not situated on a tubercle.

Length of partly engorged larva, $0.37 \mathrm{~mm}$.; width, $0.25 \mathrm{~mm}$. 
Type host.-California pocket mouse (Perognathus californicus californicus).

Type locality.-Berkeley, Calif.

Type slide.-U.S.N.M. No. 1027.

Eight specimens at hand, received from S. B. Benson, October 1, 1929. This species differs from all other chiggers known to the writer in the form of its chelicerae and in the number of dorsal abdominal setae present.

\section{HANNEMANIA PENETRANS, new species}

Plate 3, Figure 4

Palpi rounded laterally; first, second, and third setae simple, second equal to first in length, third much shorter. Palpal thumb small, inconspicuous. Palpal claw short, very sharp, trifurcate; middle prong the stoutest and longest; accessory prongs subequal. Chelicerae but slightly curved, each ending ventro-distally in a flattened spearhead, which is irregularly serrate on outer margin, basal process conspicuous and armed with three teeth on postero-dorsal aspect. Dorsal plate broader than long and posteriorly outwardly curved; submedian setae shorter than the antero-lateral, the latter shorter than the postero-lateral. Pseudostigmata situated behind a line drawn between the pair of postero-lateral setae, each about equal distance from the other pseudostigma and the postero-lateral seta on its own side; one pair of slits present, these being straight, diagonal, and situated just behind the pseudostigmata; pseudostigmatic organs short, simple. Dorsal setae about 20. Legs rather short; tarsus I with very sharp dorsal spine situated about its length from the base of the segment, subapical seta setiform, not situated on a tubercle, and extending to the base of the tarsal claws.

Length of partly engorged specimen, $0.81 \mathrm{~mm}$; width, $0.49 \mathrm{~mm}$.

Type host.-Leopard frog (Rana pipiens).

Type locality.-Great Falls of Potomac, Va.

Type slide.-U.S.N.M. No. 1028.

Described from eight specimens; two taken from a green frog (Rana clamitans), collected at the type locality September 21, 1926, by the writer; four taken from leopard frogs (Rana pipiens), at type locality, August 27, 1930, by H. E. and Paul Ewing; and two from same host and locality, September 24, 1930, by same collectors. This species is nearest to $H$. eltoni Sambon but has the palpal claw trifurcate and short pseudostigmatic organs. 


\section{EXPLANATION OF PLATHS}

(Drawings by Eleanor A. Carliu)

\section{Plate 1}

Figure 1. Trombicula blarinae, new species; dorsal plate.

2. Trombicula dunni, new species; dorsal plate and eyes.

3. Trombicula cervulicola, new species; dorsal plate and eyes.

4. Trombicula piercei, new species; central view of palpus.

5. Trombicula cavicola, new species, palpal claw from below.

\section{Plate 2}

Fiqure 1. Neoschöngastia signator, new species; dorsal view.

2. Neoschöngastia scelopori, new species; lateral view of chelicera.

3. Neoschöngastia scelopori, new species; side view of tarsus I.

4. Neoschöngastia brevipes, new species; dorsal plate and eyes.

\section{Plate 3}

Frgure 1. Endotrombicula penetrans, new species; outer view of chelicera.

2. Endotrombicula penetrans, new species; dorsal view of cephalothorax.

3. Hannemania hirsuta, new species; ventral view of chelicera.

4. Hannemania penetrans, new species; lateral view of chelicera.

5. Hannemania hirsuta, new species; dorsal plate and eyes. 

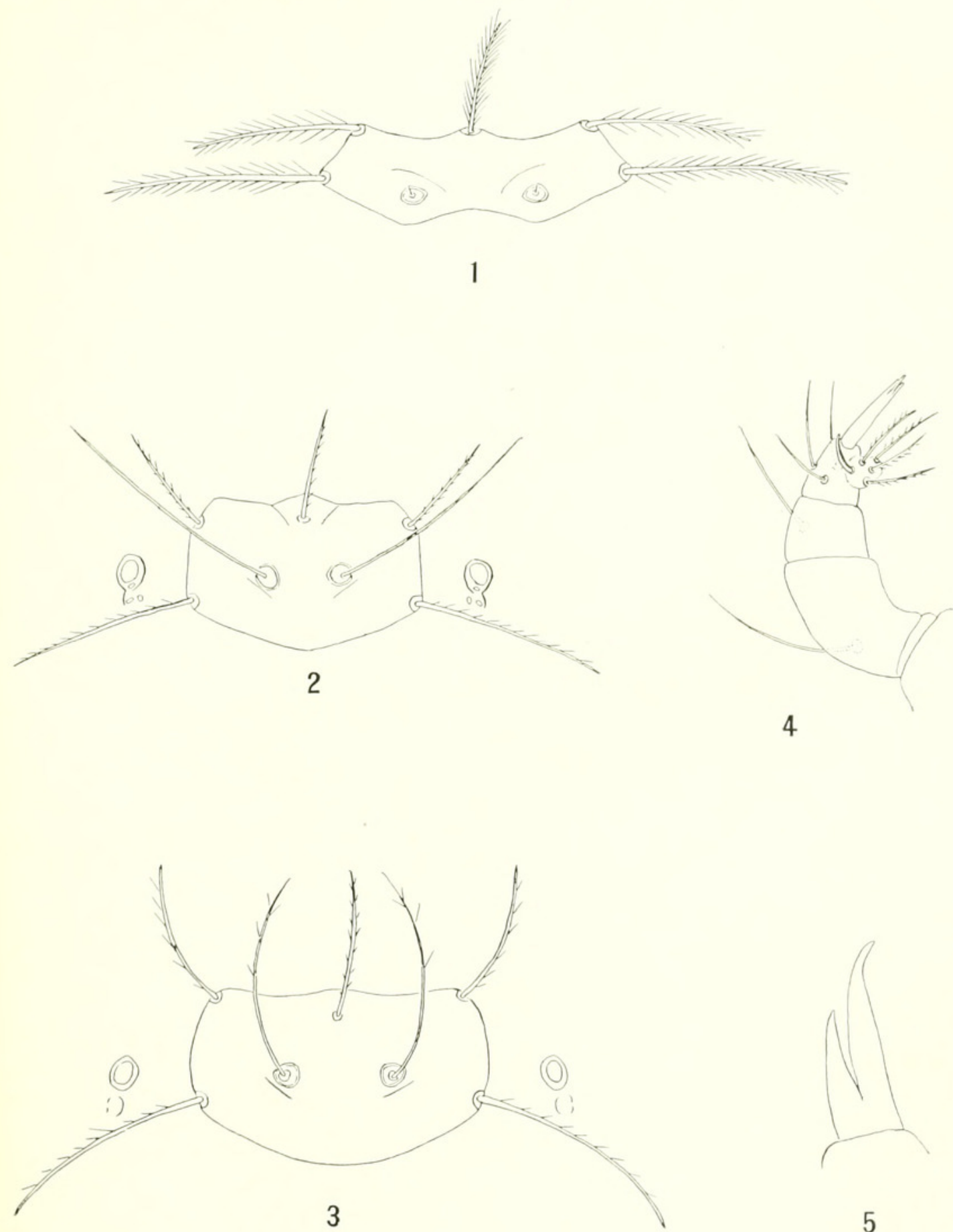

NEW SPECIES OF TROMBICULA BERLESE 

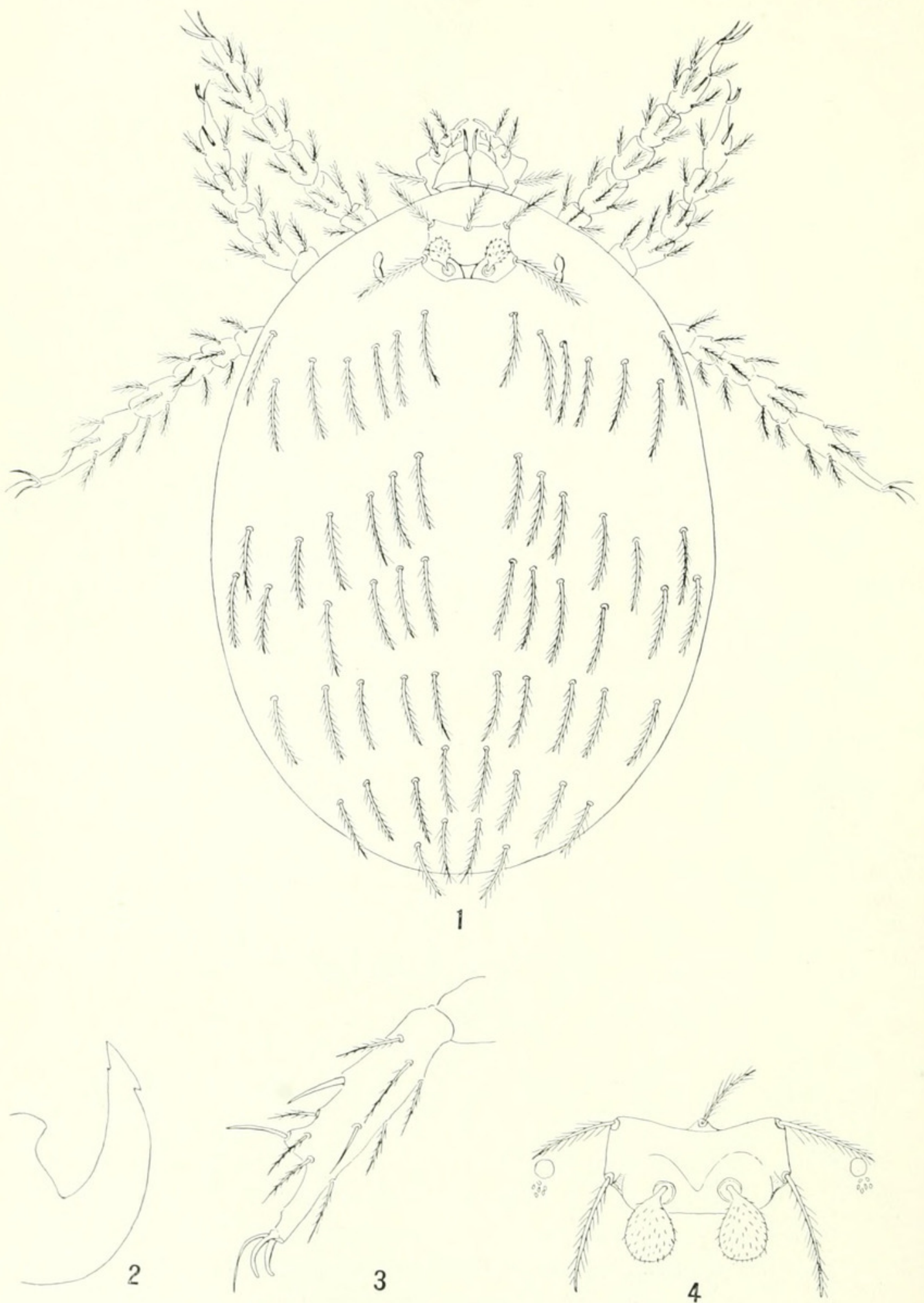

NEW SPECIES OF NEOSCHÖNGASTIA EWING FOR EXPLANATION OF PLATE SEE PAGE 19. 

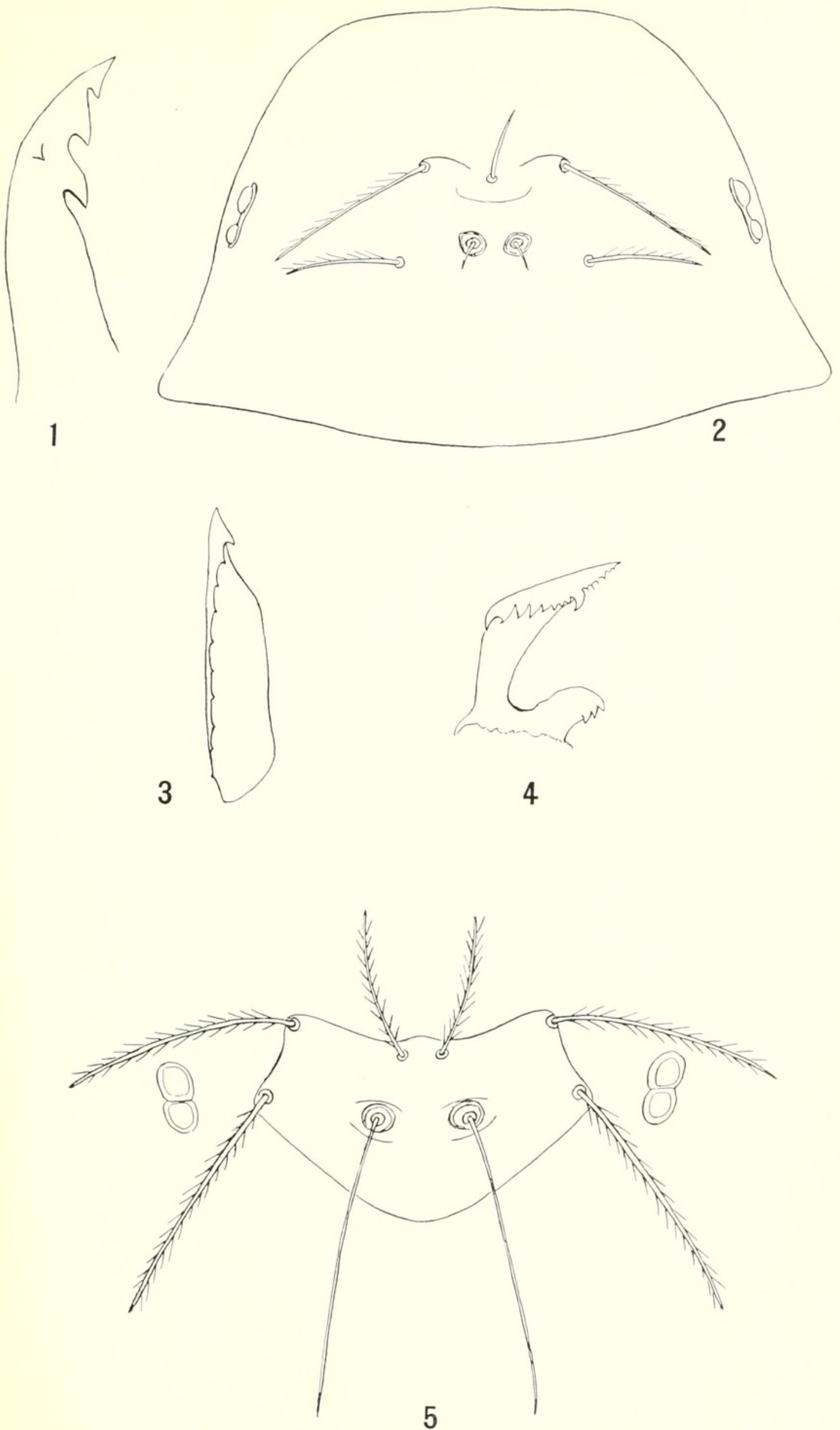

Endotrombicula penetrans, NEW GENus and SPECIES. AND NEW SPECIES OF HANNEMANIA OUDEMANS

FOR EXPLANATION OF PLATE SEE PAGE 19 


\section{$2 \mathrm{BHL}$ Biodiversity Heritage Library}

Ewing, H. E. 1931. "A catalogue of the Trombiculinae, or chigger mites, of the New World with new genera and species and a key to genera." Proceedings of the United States National Museum 80, 1-9.

View This Item Online: https://www.biodiversitylibrary.org/item/32574

Permalink: https://www.biodiversitylibrary.org/partpdf/30274

\section{Holding Institution}

Smithsonian Libraries

\section{Sponsored by}

Smithsonian

\section{Copyright \& Reuse}

Copyright Status: NOT_IN_COPYRIGHT

Rights: https://www.biodiversitylibrary.org/permissions/

This document was created from content at the Biodiversity Heritage Library, the world's largest open access digital library for biodiversity literature and archives. Visit BHL at https://www.biodiversitylibrary.org. 